\title{
Válaszkeresés járvány idején a felmerülő erkölcsi kérdésekre
}

\author{
Kránitz Mihály \\ Pázmány Péter Katolikus Egyetem Hittudományi Kar, Budapest, Magyarország \\ Beérkezett: 2021. június 24., Elfogadva: 2021. augusztus 5.
}

\begin{abstract}
Összefoglalás
Most már második éve általános tapasztalat - és nemcsak egy kis területen, hanem az egész világon - a COVID-19 halálos járvány terjedése (az elnevezés pontosan: SARS-CoV-2), amelyet már nem lehetett egyszerú megfázásnak vagy gyorsan elmúló betegségnek tekinteni, hanem egy olyan súlyos állapotnak, mely fenyegeti minden ember életét, függetlenül attól, hogy ki hol él. Az egészségügyi kutatók az ellenanyag kifejlesztéséért küzdöttek, mely megállíthatja a vírus terjedését. A gyógyítás kérdései mellett azonban filozófiai és vallási kérdések is felmerülttek, melyekre pszichológusok és hittudósok is keresik a választ. Az ember teremtettségéból és szabad akaratából kiindulva a jelen tanulmány a Bibliában közölt kinyilatkoztatás és a keresztény tanítás alapján vállalkozik nemcsak lehetséges válaszokat adni, hanem a járvány komolyságával számolva a jelenség hitbeli és teológiai magyarázatát is megfogalmazni.
\end{abstract}

Kulcsszavak: járvány, COVID-19, kinyilatkoztatás, bűn, büntetés, betegség, sorscsapás, Ószövetség, Újszövetség, keresztény hit, örök élet

\section{Searching for answers to moral issues that arise during an epidemic}

\author{
Mihály Kránitz
}

Pázmány Péter Catholic University Faculty of Theology, Budapest, Hungary

\begin{abstract}
Summary
The Covid-19 epidemic, which began in late 2019 and early 2020, has reached everyone: the family, the workplace, and public life. The phenomenon also requires a comprehensive solution. The unfortunate experience has taught everyone that there is no age limit for the virus because it affects everyone equally. It has become clear that it is not individual solutions that are needed, but only community path finding, that no one lives alone in isolation. Throughout its two-thousand-year history, Christianity has accompanied man in both its successes and failures.

God's revelation-based teaching is unchanged and to this day He provides His resulting answers to everyone by placing the whole man before God. This Christian-minded anthropology means that man lives in a personal relationship that assigns him to God alone. In terms of faith, it thus approaches the crisis, the disease, the drama of being, in a different way, which sees the reality of life and death in a greater context.

The spread of the current epidemic has been interpreted by many as a divine punishment. But God, the Creator, who is good, cannot be the source of good and evil at the same time, he cannot be the starting point of evil. It is precisely because of these characteristics that spiritual and moral behavior is valued in the epidemiological situation. Christianity does not see God-consciously directing punitive action in unpleasant events for people and humanity, as God is first and foremost a Father.

In the Old Testament, there is no connection between a particular disease or other plague and the personal sins of those who suffer it. Far from the New Testament, the conclusion is that it links the plagues, diseases, and epidemics we experience to the sins committed by individual people. The turn of the New Testament, then, is also significant in the presentation of God. It is no longer the image of the fearsome and terrible God that emerges, but the teaching of Jesus, who says of His Father, "God is love." The God of the New Testament is a God of co-suffering and compassion who thinks not of punishment but of forgiveness.

Troubles are not necessarily attributable to the sins of individuals, but actually to the sins of all mankind. Therefore, it is necessary for everyone to feel somehow responsible for the other when they see that their sins continue. However, the viral situation has also shown unparalleled human behaviors and values, especially on the part of health-
\end{abstract}


care professionals. Perhaps involuntarily, among those who acted for others, man's better self manifested itself, so they were able to make sacrifices as well. Of them, too, Jesus said, just before his suffering, that "no one loves more than he who gives his life for his friends." It is love that overcomes fear, that can be the cure for a virus.

Keywords: epidemic, COVID-19, revelation, crime, punishment, disease, fate, Old Testament, New Testament, Christian faith, eternal life

\section{A válsághelyzet cselekvésre szólít fel}

2019 végén, 2020 elején a koronavírusok családjához tartozó, eddig ismeretlen, új, COVID-19-nek nevezett vírus tứnt fel, mely az emberiség egészét mindennapi életében érintette. Amire visszaemlékezünk, a múlt, az valójában a mi múltunk. Mára tulajdonképpen nincs olyan ember a világon, aki környezetében, családja vagy rokonai körében ne találkozott volna a vírus okozta betegséggel vagy halálesettel. Kisebb-nagyobb betegségeken már mindenki átesett, de ennek az új jelenségnek a hatásával senki sem számolt. A fertőzöttek és a halálos esetek nagy száma a közös cselekvés igényét váltotta ki.

A járvány valamiképp mindenkit érintett: a családban, a munkahelyen és a közéletben egyaránt. Mivel ez alól senki nem tudja kihúzni magát és a fenyegetettség folyamatos, ezért maga a jelenség is átfogó megoldást igényel. Az orvostudomány a láthatatlan módon terjedő vírussal szemben csak lemaradva képes új gyógyszerek elóállításával válaszolni. Ráadásul a hatásosnak nevezett gyógyszer csak bizonyos mértékben nyújt védelmet és csak a betegség egy adott típusával szemben. Ez az érzés tehetetlenséget vált ki sokakból, mert önmagukat eleve legyőzöttnek tekintik a jelenlegi vírussal való küzdelemben. A fertőzötteket gyakran az elkeseredés és a magány is sújtja, nem beszélve fizikai állapotuk gyengüléséről. A végponton lévók pedig az emberhez méltó búcsúztatást sem remélhetik.

\section{Az élet értelme válsághelyzet idején}

Itt merülnek fel a megoldási kísérletek, melyek csak próbálkozások, ugyanis a kikísérletezett oltások csak egy adott vírussal szemben jelentenek védelmet, de nem adnak választ az emberek személyes helyzetére, melyben fenyegetve érzik magukat. Meg is kérdezhetjük: Jó volt-e az az irány, amely felé eddig nagy általánosságban az emberiség tartott? Most az új helyzetben még határozottabban áll előttünk az élet értelmének kérdése. A mindeddig biztosnak hitt tudomány, a modern technológiai és informatikai rendszerek bizonytalanok lettek egy nem várt „ellenséggel” szemben. A termelési és fogyasztási ideológiák lendülete megakadt, és a világ globális irányításában részt vevők minden más közéleti szereplővel együtt csak tapogatóznak a helyes út megtalálásában, az eddigi kiszámítható múködés visszaszerzésének reményében.

Megváltoztak az emberi korokhoz kapcsolódó elképzelések is, és a sajnálatos tapasztalat tanított meg min- denkit arra, hogy a vírus előtt nincs korhatár, mert az mindenkit egyformán sújt. Világossá vált, hogy nem az egyéni megoldások, hanem csakis a közösségi útkeresések bizonyulnak helyesnek, ugyanis senki nem él csak elszigetelten önmagának. Még ha magányos is, akkor sem vonhatja ki magát a társadalom életéból, és éppen a vírus általános megnyilvánulása gondolkodásra késztetheti az elmúlt évtizedek során a korlátlan fejlődésbe beleszédült világot.

Voltak, akik már jelezték egy sokáig körülírhatatlan esemény bekövetkezését, mely globális szinten érintené az egész emberiséget, de ennek a megvalósulásáról senki nem tudott biztosat mondani. Bizonyos elójelek már évekkel ezelőtt is voltak egyes jól lehatárolt területeken (környezetszennyeződés, felmelegedés, természeti források kimerülése stb.), de a nagyfokú kiterjedést és az emberiség teljes veszélyeztetettségét még nem lehetett érezni.

Bármekkora fejlődésen is ment át az emberiség az elmúlt száz évben az egészségügyi, gazdasági, múszaki területen, az emberi lét végességével mégis mindenhol számolni kellett. Ezen a ponton szólalhat meg a kereszténység, mely kétezer éves története során végigkísérhette az embert sikereiben és kudarcaiban egyaránt. Tanítása változatlan mind a mai napig, és az ebből fakadó válaszait a mindenkori ember helyzetére nem annak külső, változó jelenségeiből vezeti le, hanem belső rendeltetéséből, úgy, hogy a teljes embert az Isten színe elé helyezi.

Ez azt jelenti, hogy az ember nem pusztán a vágyaiban él, hanem egy olyan személyes kapcsolatban, amely ôt egyedül Istenhez rendeli. Tulajdonképpen ez minden egyes vallásnak is a meghatározása, azonban egyedül a kereszténység tudott - nem emberi erôből vagy okoskodásból a legnehezebb élethelyzetekre is - választ adni, köztük a betegségre és a halálra, mivel tanítása nem emberi tudomány vagy kísérletezés következménye, hanem isteni megnyilvánulás, mely nem korszakokhoz kötődik, hanem egyetemes érvényú, ezért biztató „örömhír” lehet azoknak, akik hittel elfogadják (vö. Jézus szava: „Én vagyok az út, az igazság és az élet" Jn 14,7).

A hit szempontjából így más módon is közelíthetünk a válsághoz, a betegséghez, a lét drámájához, amely egy nagyobb összefüggésben látja az élet és a halál valóságát, és éppen a bennünket nyugtalanító jelenségre is tud mind ez idáig kevésbé figyelembe vett szempontok alapján értelmet adni. Ez rendkívül fontos, mivel „kevés időt ad" a gátlástalan vírus, fóleg a súlyos állapotban lévơknek. 
Egy krízis, egy válság vagy éppen egy járvány idején személyes sorsunkkal kapcsolatban érdemes elgondolkodni, hogy saját jövőnket illetően is biztonságban legyünk az örök élet üzenetével megerősítve.

\section{A járványok értelmezése az egyházban}

A jelenlegi járvány elterjedését sokan isteni büntetésként értelmezték. Ez előfordult a keresztény felekezetek, de más nem keresztény vallások és vallási jelenségek részéről is. A magyarázat alapvetően hagyományosnak mondható vallási környezetből származott, mely néha erőteljes szavakkal fejezi ki véleményét: Isten a jelenlegi büneik miatt bünteti az embereket, a hitetlen, anyagelvú, erkölcsileg eltévelyedett, az abortuszt és az eutanáziát támogató személyeket. Előfordult ennek enyhébb, pedagógiai jellegú változata is: Isten figyelmeztetésként bocsátja az emberekre a betegséget, hogy ismerjék fel eltévelyedésüket és tartsanak bünbánatot. Alapvető szándéka nem annyira a büntetés, inkább a nevelés, a kiigazítás. Az értelmezésekben két alapelgondolás érvényesült: 1) közvetlen kapcsolat van a csapás és a jelenlegi búnök között; 2) a csapás magától Istentól vagy az ő akaratát teljesítő fő́angyaltól vagy angyaltól származik.

Egyesek ezeknek az értelmezéseknek még teológiai hátteret is adtak: 1) mivel Isten mindenható, minden az ő akaratára vezethetô vissza, és ez alól senki nem vonhatja ki magát; 2) ha másvalakinek vagy másvalaminek tulajdonítjuk a csapás okát, akkor Isten mellett el kell fogadnunk egy másik hatalmat, legyen ez a jó vagy a rossz princípiuma, ez azonban manicheus, azaz gnosztikus eretnekség lenne. Ez a felfogás viszont egy másik következtetést is eredményez: Isten, aki jó, nem lehet egyszerre a jó és a rossz forrása, ő nem lehet a rossz kiindulópontja. Így tehát a csapások, amelyekkel az embereket sújtja búneik miatt, jónak mondhatók - ebben az a korábbi elgondolás jelenik meg, hogy az embereket a bünöktốl való elfordítással és az Istenhez való közelítés szándékával kell nevelni.

Ezeket az elképzeléseket azonban maga az orvostudomány fejlődése cáfolta. Az érzékelhető eseményeknek egy magasabb okra való visszavezetése egy kezdetleges társadalom és vallásosság sajátja. Helyes értelmezésüket tulajdonképpen az addig ismeretlen mikrobák (baktériumok és vírusok) „gyengítették”, melyek tulajdonságait éppen a COVID-19-járvány tartós jelenléte is megerősített, valamint az ellenszer gyors kidolgozásának a szükségessége. A XIX-XX. században megtapasztalt járványok eseményei mutatják, hogy nem éledtek újjá a múlt sokszor irracionális magyarázatai, és nem merültek fel újak.

Az értelmezés szempontjából egy másik kérdéssel is számolni kell, ha a járványt állítólagos isteni büntetésnek vagy isteni nevelési módszernek tekintjük. Ne felejtsük el, hogy kezdetben a pogányok éppen a keresztényeket okolták a járványok, az éhínség, a szárazság vagy a háborúk megjelenésekor. Tertullianus (155-222) éles iróniával ad választ ezekre a vádakra hitvédelmi írásában: „Ha a Tiberis kiárad a városban, ha a Nílus elárasztja a falvakat, ha az ég nem ad esőt, ha a föld megrendül, ha éhség, ha járvány van, azonnal kiáltják: az oroszlánok elé a keresztényeket!" (Tertullianus, Apologeticum, XL,2.)

Karthágói Ciprián idején (251-171) Demetrius császár tette felelőssé a járványért a keresztényeket, mivel azok elfordultak a bálványoktól és más „istent” imádtak, mint a pogányok. Ciprián egy tanulmányban válaszolt a császár vádjaira (vö. Karthágói Szent Ciprián, Ad Demetrianum, Válasz a pogány vádak ellen). Néhány évvel később pedig a kappadókiai Caesarea püspökétól, Firmilianustól kapott levelet, amelyben ôt arról értesíti, hogy 235-ben a Kappadókiát és Pontuszt megrázó földrengéssorozat következtében erőszakos keresztényüldözés tört ki. Szent Ágoston egyik érve a Civitas Dei (Isten városa) megírására éppen az volt, hogy Róma Alarik általi elfoglalását (410) éppen a keresztényeknek számították be, mivel ők „elhagyták” azokat az isteneket, akik a várost naggyá tették.

Fontos annak megállapítása, a vírus és a világjárvány idején még inkább, hogy annak nincs közvetlen kapcsolata a lelki adottságokkal. Úgy a múltban, mint a jelenben, az efféle jelenség egyaránt megnyilvánult különböző országokban és területeken, függetlenül azok vallásától, hiedelemvilágától vagy erkölcsi döntéseitől. Korábban néhány súlyosabban érintett terület mégis isteni büntetésnek tulajdonította állapotát. Így a „fekete pestis" (1347-1466), mely a Bizánci Birodalmat sújtotta, sajátos értelmezés szerint a muzulmán hódításnak készített utat. Bizonyára a XIV. század során az ókori humanizmus feléledése gyengítette a birodalmat, de nehéz értelmezni, hogy Isten azért büntette volna a bizánci keresztény birodalmat, hogy előkészítse az ottomán uralkodók és végső soron az iszlám terjedését.

\section{Hol és hogyan terjed a járvány, mi a kiváltó oka?}

A különböző országokban a járvány a személyek közötti kapcsolatok és a fizikai, korhoz kötött erőnlét összefüggésében kapcsolódhat egy meglévő társbetegséghez, de nem egy vallási vagy erkölcsi szempont alapján. Enélkül felfoghatatlan, hogy a keresztény értékek szerint élő időseknek és az erkölcsileg ártatlan gyermekeknek miért kellene egy társadalom etikai tévelygései miatt isteni büntetésben részesülni, amikor a búnökért nem is felelősek. Vajon a betegeket lelkileg támogató papokat és az önzetlen gondoskodást nyújtó, felebaráti szeretettel megnyilvánuló orvosokat, ápolókat, akik szintén ki vannak téve az életveszélynek, Isten miért büntetné vétkeikért? Miért sújtaná őket ezekkel a megpróbáltatásokkal, amikor a szeretet parancsát a legtökéletesebb módon teljesítik és munkájuk is nagy áldozatot követel tőlük? A jelenlegi járvány egyaránt sújtotta a szerzetesházakat és más egyházi intézményeket is, akiket miért kellett volna nevelő célzattal büntetni. 
A jelenség értelmezésére más eszközeink is vannak. Nagyon is tudjuk, hogy a vírus gyors terjedése kifejezetten sújtotta az idősotthonokat, akik sajátos közösségi életük miatt az őket látogatók miatt fertőződtek meg. Előfordult, hogy éppen liturgikus szertartás során terjedt a betegség, bármennyire is csökkentették a zárt templomokban megtartott szertartások számát. Ez ismét értelmezhetetlenné teszi a vallási gyakorlatot követőknél az isteni büntetést, összevetve azokkal, akik otthon maradtak, $\mathrm{s}$ emiatt nem váltak érintetté.

Mindemellett érdemes megfontolni azt is, anélkül hogy Isten döntéseként értelmeznénk, hogy van-e valami neveló értéke az epidémiának, mint minden egyéb megpróbáltatásnak, amelyet a társadalom átél, és súlyosan érinti annak múködését és teszi bizonytalanná jövőjét, megfosztva tagjainak jelentős számától. Így ez mégiscsak hatással van a döntésekre, az értékekre és az életmódra, és kikerülhetetlenül bizonytalanná teszi a jövőre vonatkozó tervezést. Éppen a járvány elkerülhetetlen lefolyása vet fel kérdéseket a fogyasztói társadalommal, valamint a szüntelen profitéhség következtében kialakult fejlődésideológiákkal kapcsolatban, végső soron a mondializációval, vagyis a homogén, egyetlen világban való gondolkodással, mely függő́séget és munkanélküliséget eredményezett a nyugati országokban. Itt megjelennek a politikai-gazdasági tényezők is, melyek mélységesen materialista jellegüknél fogva érintik a személyek gondolkodás- és életmódját, de közvetve lelki hatást is eredményeznek.

Az említett, állandó fejlődésben lévő társadalmak nagyon gyorsan szembesültek minden tudomány ellenére az általános emberi törékenységgel. Kevésbé tartották szem előtt, hogy bár a múlt nagyon sok betegségét a tudomány legyőzte, ezek helyét újabbak, sokszor félelmetesebbek vették át. Ezek szinte szempillantás alatt kérdőjelezték meg a transzhumanizmust, amely egy ideje már a technológiailag fejlettebb országok nézetévé vált. A vírus terjedése hívốt és hitetlent, vagyis minden embert a saját egészségének, életének, anyagi javainak hiábavalóságára emlékeztetett.

Ismét megjelent az őskeresztény korban is figyelmeztetésként szereplő memento mori ('emlékezés a halálra'), a halandóság tudatának folyamatos ébren tartása, és a tény, hogy a halál egyik pillanatról a másikra, váratlanul, mint a „tolvaj” - Pál apostol szavai szerint (ITesz 5,2) -, meglephet bennünket. Éppen eme adottságok miatt értékelődik fel a lelki-erkölcsi magatartás a járványügyi helyzetben. Általánosságban kell rákérdezni, hogy ez mennyire hallható, illetve volt vagy lesz majd hallható. Kétségtelen, hogy a lelkileg érzékenyebbeknél, akik között a hívőket is megtaláljuk, különböző magatartásformák léptek fel a korlátozások miatt és a szentségekhez való járulás akadályozásával.

A többség a járvány előtti élethez való visszatérést keresi, bár a közéleti szereplők is hangsúlyozzák, hogy „a járvány után már nem lesz minden úgy, mint korábban volt", a médiában kezdtek megjelenni a járvány utá- ni világ új szempontjai, melyek azonban sohasem utaltak a hitre vagy egy természetfeletti vonatkozásra. Bár a közfelfogásban ott szerepel a halál általános tagadása, a járvány mindenki számára egy lehetséges és közeli halál képét is felmutatta.

A sajátos kortárs gondolkodás inkább elodázza és így kiiktatja a halállal való szembenézést a közbeszédből, melyről mindig harmadik személyben és többes számban beszélnek, anélkül hogy első vagy második személyben lehetne gondolni egy közeli elhunytra vagy a személyes érintettségre. Szent Ciprián a tanúja kora járványterjedésének, mellyel kapcsolatban megállapítja, hogy „senki sem gondolja magáról, hogy ő is halandó" (Karthágói Szent Ciprián, Ad Demetrianum, XI,1.).

Még közvetlen hozzátartozóink halála is önkéntelenül és drámai módon „távolabb” került tôlünk. A kórházakban és az idősotthonokban elhunytakat sokszor gyászszertartás nélkül temették el, az élőktől távol. Előfordult, hogy az élők, akik nem láthatták szeretteiket, még holtukban sem tehették ezt meg, s ezzel a gyász méltósága is csökkent. A halál így az „elvont” világba került át. A halálfélelem viszont sok esetben lefoglalta személyiségüket, nem hagyva helyet a lelki szempontoknak, ami éppen egy hívő, egy vallásos ember és egy keresztény esetében nemcsak a közeli halálra vonatkozik, mivel az egy "egész élet” feladata. Felidézve a sztoikusok mondását: „élni annyi, mint felkészülni a halálra”, amit a sivatagi atyák is elöszeretettel magukévá tettek az „emlékezz a halálra" mindennapi feladataként.

A modern korban viszont éppen ez a szempont túnt el teljesen az emberek szeme elől: a halálról való elmélkedés, a halál számításba vétele és a halálra való felkészülés gondja, amint erre a filozófus Martin Heidegger (18891976) utal, ez „„öldi jövőnk egyetlen bizonyossága” (Heidegger, M., Sein und Zeit, 11. ed., Max Niemeyer Verlag, Tübingen 1967, 235-267.). Az is megfigyelhető volt, mint a nagy járványok idején, hogy az emberek egyszerre tudtak helyesen és helytelenül dönteni. Szent Ciprián említett levelében is már szóvá teszi, hogy az általa is megtapasztalt járvány során voltak, akik a szenvedélyeik szerint éltek, mások viszont felebarátaik iránt hősies szeretetet mutattak (Karthágói Szent Ciprián, Ad Demetrianum, X,2-XI,1.).

Összegzésként elmondható, hogy a járványok és más hasonló sorscsapások csak azoknak tanulságosak, akik már tanultabbak. Élettapasztalatukat ezzel tökéletesítik, szemben azokkal, akik semmilyen tanulságot nem vonnak le a maguk számára az eseményekből, azok kétségbe esnek.

\section{A Szentírás válasza a megpróbáltatásokra}

A kereszténység nem lát Istentől tudatosan irányított büntető intézkedést az emberek és az emberiség felé megvalósult kellemetlen eseményekben, mivel Isten mindenekelőtt Atya. Krisztus maga is azt kérte, hogy így szólítsuk őt a legelső keresztény imádságban: „Mi Atyánk!" (vö. Mt 6,9). El tudunk képzelni egy olyan 
„apát”, aki gyermekei nevelésére a fájdalmat és a halált is okozó vírust küldi? Éppen ellenkezóleg, egy olyan Atyát kell elképzelni, aki végtelenül meghaladja az emberi atyaságot, és - amint számos modern teológus hozzáteszi - az anyaság valamennyi minőségét is.

A járvány általi isteni büntetés feltételezése ellentmond a lelki megfontolásoknak, mert ha ez valóban így lenne, akkor lehetőség sem nyílna arra, hogy ez elól elfussunk, védekezzünk ellene, vagy óvjuk magunkat, mert éppen az isteni akarattal lenne ellentétes, ha menekülnénk az isteni döntés elől. Ezeket a kérdéseket nemcsak a valláson kívül állók, hanem maguk a keresztények is felteszik, ám ez a feltételezés soha nem volt keresztény álláspont, még ha néhány szélsőséges elképzelés született is erről.

Már a keresztény ókorban is egységes felfogás volt arról, hogy bajban nem keresztény orvoshoz is lehet fordulni a gyógyításért, ső́t éppen a püspökök voltak az elsők, akik a korabeli társadalmakban a gyógyítás intézményét létrehozva kórházakat alapítottak (Eftychiadis, A. C., The Early Types of Hospitals During the First Three Christian Centuries and the Early Byzantine Period, in Theologia 68 [1997], 288-311.). Amikor a betegek Krisztushoz járultak, ő sohasem utalt arra, hogy jogos büntetésként szenvedik el betegségüket, és hogy nem kell gyógyulást keresniük, hanem éppen ellenkezőleg: meggyógyította ôket.

A Szentírásban számos olyan helyet találunk, ahol a sorscsapásokat Istentől származónak mutatják. Valójában azonban csak fenyegetésekről van szó, amelyek nem valósultak meg (vagy pedig figyelmeztetésekról, melyeknek nem volt további megnyilvánulása). Egyetlen eset van, ahol az Isten által küldött pestis megtizedeli a népet Dávid király idejében (2Sám 24,13-15; vö. 1Krón 21,11-14). Ez csak egy nagyon lehatárolt földrajzi területre vonatkozott, és ez az egyetlen pestis, amelyet az Ószövetség által ismertetett hosszú történelmi idő a térségben lévő számos más pestis közül megemlítenek.

A vízözön történetének a végén - mely Noé családján és azokon kívül, akik a bárkába menekültek, minden élőlényt elpusztított a földön - Isten kijelenti, hogy hasonló többé nem fog megtörténni: „Az ember miatt nem átkozom meg többé a földet, hiszen az emberi szív vágya ifjúkorától kezdve hajlik a rosszra. Nem törlök el még egyszer minden élőlényt, ahogy megtettem" (Ter 8,21).

Az Újszövetségben egy alkalommal találkozunk a járvány kifejezéssel. Krisztus utal az idők végének eseményeire: „Nagy földrengés lesz itt is, ott is, éhínség és dögvész. Szörnyú tünemények és különös jelek tûnnek fel az égen" (Lk 21,11 - loimoi kai limoi: lomosz 'pestis' és limosz 'éhínség'). Ezeket Lukács evangéliuma nem mint Isten által akart eseményeket mutatja be, és nem is úgy, mint amiket Isten hajt végre büntetésként. Fel lehet idézni még az Apostolok Cselekedeteiben található utalást, ahol Agabusz próféta jövendöli meg az éhínséget (ez egy másfajta valóság, amely az emberek nagy részét sújtja: erről egyáltalán nem úgy szól, mint egy csapásról, nem hozza összefüggésbe semmilyen búnnel, ám utalás történik az apostolok válaszára, akik gyúijtést rendeznek a nehéz helyzetbe jutottak számára (vö. ApCsel 11,28-30).

\subsection{Az ószövetségi felfogás értelmezése}

Egy adott betegség vagy más csapások és az azokat elszenvedők személyes búnei között nincs összefüggés, és különbség van Isten bemutatásában. Láttuk, hogy az Ószövetségben a járványok Isten által küldött csapásként is szerepelnek, az emberi búnök büntetésére. Valójában azonban csak fenyegetésekról van szó, és az egyetlen járvánnyal kapcsolatos eset, amelyről a Biblia beszámol, Dávid király személyéhez köthető (2Sám 24,13-15; 1Krón 21,11-14). A pestis, amely Isten büntetéseként sújtotta Izraelt, Dávid táborában hetvenezer áldozatot követelt, és egy behatárolt területen pusztított. A környező országokban ismert más járványok közül ez az egyetlen, amelyet a Szentírásban megtalálunk az Ószövetség hosszú idejéből.

Összefoglalásul elmondhatjuk, hogy az Újszövetségben egyáltalán nincs alapja annak, hogy a járványok Istentől származó büntetések lennének.

Egyúttal az Újszövetségben sajátos fordulatot tapasztalunk a betegség és a személyes bún összefüggésében, valamint Isten bemutatásában. Az Ószövetség az egészséget, a termékenységet, a gazdagságot az igaz emberek adottságaként értelmezi, míg a betegség, a terméketlenség, a szegénység a bünösre sújtó csapásként szerepel. (Ezekrőll szól részletesen a Második Törvénykönyv 28. fejezete.)

Az Újszövetségtől távol áll a következtetés, mely öszszekapcsolja a megtapasztalt csapásokat, betegségeket és járványokat az egyes emberek által elkövetett bünökkel, melyek kiterjednek a közvetlen leszármazottakra is. A Prédikátor könyvében még azt is olvashatjuk: „Mindenkire egy és ugyanaz a sors vár" (Préd 9,2). Ez utóbbi jelenik meg teljes mélységében Jób könyvében, mely két fontos tanítást tartalmaz a Jóbot és általában az emberiséget ért csapásokról: 1) ezek a csapások nem a személyes bün büntetései, 2) nem Istentől, hanem a sátántól származnak. Jób barátai viszont azt akarják bizonyítani, hogy öt a saját bünei miatt jogosan érte Isten büntetése (vö. Elifáz [Jób 5,17.15.20.35]; Cófár [Jób 27,13-24]; Elihu [Jób 33,12]). Érveléseik ama ószövetségi felfogásban helyezhetók el, mely szerint Isten a jókat megjutalmazza, a gonoszokat azonban megbünteti. Ez az elképzelés ugyanakkor Jób könyvében végig jelen van.

Jób barátai tehát azt a nézetet képviselik, hogy Jób szükségszerúen szenved, mert bűnt követett el. Ha ez nem így lenne, akkor továbbra is élvezné élete boldogságát, és semmiféle csapás nem érné. Itt tehát egyfajta rejtett, Jób által nem ismert búnösségről lenne szó, amelyről őt meg kell győzni. Jóbnak ezért bünbánatot kell tartania, mert ez az egyetlen mód, ahogyan megszüntetheti a csapásokat.

Ebben az esetben egy hamis istenkép érvényesül, amely csapásokkal sújtja az embert, mégpedig a szemé- 
lyes bűnei miatt. Jób védekezésében hárítja el érvelésüket: „Hamis beszédekkel mentitek az Istent, tán még hazudnátok is a védelmére" (Jób 13,7). Jób könyvéből nyilvánvaló, hogy nincs szükségszerü kapcsolat az emberi élet során elszenvedett bajok és a lehetséges személyes bűnök között. Ugyanakkor a könyv elején azt is olvashatjuk, hogy ő még gyermekei rejtett büneiért is égőáldozatot mutatott be (vö. Jób 1,5).

Jób nem fogadja el Isten immanens igazságosságának elképzelését. Számára világos, hogy maga a valóság cáfolja azt, hogy az ember a büneiért szenvedné el a sorscsapásokat, mivel számos igaz is hasonlóképpen szenved. Ez a valóságlátás az Ószövetség más könyveire is érvényes, melyek kifejezik, hogy a sorscsapások mindenkit egyformán sújtanak, sőt előfordul, hogy a gonoszoknak jobb a helyzetük, mint az igazaknak: „Irigység fogott el a gonoszokkal szemben, látva, milyen jól megy soruk a bünösöknek [...]" - állapítja meg a zsoltáros (vö. Zsolt 72,312). „Miért szerencsések a gonoszok, miért élveznek békét a hütlenek?” - kérdezi a próféta (Jer 12,1). Más próféták is hasonlóképp fogalmaznak: „Most lám, boldognak mondhatjuk a kevélyeket, akik gonoszságot múveltek, azoknak jól megy a soruk. Próbára teszik az Istent és semmi bántódásuk nem esik" (Mal 3,15).

\subsection{Az Ujszövetség és a helyes istenkép}

Az Újszövetséget is figyelembe véve egyértelmü, hogy nincs közvetlen kapcsolat a betegség, a gyengeség és az elkövetett bűnök között. Több esetben Jézus nyíltan fogalmaz. Például a vakon születettel kapcsolatban, amikor tanítványai kérdezik: „Mester, ki vétkezett, ez vagy a szülei, hogy vakon született?" - Krisztus egyértelmű válasza: „Sem ez nem vétkezett, sem a szülei” (Jn 9,1-3). A második eset a béna meggyógyításával kapcsolatos, ahol Jézus így szól: „Bízzál, fiam, bocsánatot nyertek büneid!” És a test gyógyításával folytatja: „Kelj fel, fogd ágyadat és menj haza!” Ezt a gyógyítást a szinoptikus evangéliumok idézik fel (Mt 9,1-6; Mk 2,1-12; Lk 5,17-26). Ha a testi gyengeség a bün következménye lett volna, akkor elég lett volna, ha Jézus megbocsátja a béna büneit, hogy visszakapja teste egészségét, de most lelke egészségét is visszakapja anélkül, hogy egy második beavatkozásra szükség lett volna.

Itt az egyházi gyakorlatot is érdemes figyelembe venni. Szent Jakab levelében betegség esetén azt javasolja, hogy hívják el az egyház papjait, hogy imádkozzanak a betegért és kenjék meg olajjal: „A hitből fakadó ima megszabadítja a beteget és az Úr talpra állítja. Ha pedig bűnöket követett el, bocsánatot nyer" (Jak 5,14-15). A feltételes mód használata jelzi, hogy nincs szükségszerü kapcsolat a szenvedő beteg és a bünök között, melyeket elkövethetett, mivel itt csak egy eshetőségről van szó.

Amikor Jézus a templomban a Betheszda-fürdőnél meggyógyult béna emberrel találkozik, kijelenti: „Nézd, meggyógyultál, többé ne vétkezzél, nehogy még nagyobb baj érjen" (Jn 5,14). A nagyobb baj, amelyre Jézus utal, nem egy nagyobb betegség, hanem egy bün, amelyet valószínúleg elkövetne.

Az Újszövetség fordulata tehát Isten bemutatásában is jelentős. Már nem a félelmetes és rettenetes Isten képe rajzolódik ki, hanem Jézus tanítása, aki így szól Atyjáról: „Isten a szeretet” (1Jn 4,8). Isten tehát Atya, a Fiú Atyja, de mindazoké is, akik a Szentlélek által egyesülnek a Fiúval, és így fogadott fiak lesznek.

Isten szeretetének legnagyobb megnyilvánulása saját Fiának elküldése a Földre, aki a búnt kivéve az emberi természetet teljesen magára vette, s ezzel meg is gyógyította. Ugyanakkor maga Jézus Krisztus bátran szembenézett a kísértésekkel, a fájdalommal, sőt a kereszten való önfeláldozással. Isten ezzel megmutatta, hogy Fiában teljesen közel áll az emberekhez, és nemcsak ismeri gyengeségeiket, hanem azokat magára is veszi.

Az Újszövetség Istene az együtt-szenvedés és a könyörület Istene, aki nem a büntetésre, hanem a megbocsátásra gondol. Krisztus sem ellenfelei büntetését kéri, hanem értük könyörög: „Atyám, bocsáss meg nekik, mert nem tudják, mit tesznek" (Lk 23,34). A gonosz elleni küzdelem nem fizikai, hanem lelki jellegú. Itt nem Isten mindenhatósága, hanem alázata nyilvánul meg. Egy olyan alázaté, amely megmutatja, hogy Isten az Ige személyében emberré lett (Fil 2,6-8, ez az egyik legszebb újszövetségi himnusz, mely Isten alázatáról szól). Isten nagysága nem az uralkodásban, hanem a szolgálatban nyilvánul meg. (Jézus külön felkészíti tanítványait az általános gondolkodás megváltoztatására és az áldozatvállalásra: „A tanítványok útközben, egymás között arról tanakodtak, hogy ki a nagyobb közülük. Akkor leült, odahívta a Tizenkettőt, s így szólt: »Ha valaki első akar lenni, legyen a legutolsó, mindenkinek a szolgája «" (Mk 9,34-35). (Lásd még: Mk 10,42-45: a Zebedeus fiak kérése. Jézus maga ad az új cselekvésmódra példát, amikor megmossa tanítványai lábát: „Tehát én, az Úr és Mester megmostam lábatokat, nektek is meg kell mosnotok egymás lábát.”) A legnehezebb helyzetekben tehát az együttérzés, sok esetben az együtt-szenvedés jelenik meg Jézus szavaiban és tetteiben.

Mikor nyilvános múködése során Jézushoz betegeket hoznak, elsődleges gondja a fájdalmak csökkentése és a gyógyítás. Ezzel együtt bocsátja meg büneiket, és szólítja fel óket, hogy többé ne vétkezzenek. Nem azért, mert azt gondolná, hogy a betegség a bún következménye, hanem azért, mert az embernek nemcsak teste, hanem lelke is van, és ezért fontos, hogy egész személyiségében nyerje vissza épségét, ugyanakkor a lélek (örök egészsége) fontosabb, mint a test (időbeli egészsége), jóllehet ez nem elhanyagolható. Az egyház történetében láthatjuk, hogy Krisztus betegek iránti szeretete folytatódik az általa alapított közösségben, és ez párhuzamosan halad az igehirdetői tevékenységgel. 


\section{3. Ádám büne és annak köpetkezménye}

Ádám és Éva bưne az egyházatyák szerint nemcsak az emberi természetre, hanem a környezetre, ső́t az egész világegyetemre kihatott. A kinyilatkoztatás szerint Isten utolsónak teremtette meg a legtökéletesebb teremtményként az embert, aki önmagában mikrokozmosz és ugyanakkor közvetítő a természet és Isten között. Isten a teremtés koronájává tette az embert és minden hatalmat megadott neki a természet fölött. Feladatot is adott neki, hogy múvelje és órizze azt (Ter 2,15). Isten elvárta, hogy az ember hálát adjon életéért, megköszönje minden ajándékát. Ám amikor Ádám vétkezett, ezáltal az emberi személy vált rendezetlenné. Ez nemcsak saját magát érintette, hanem minden teremtményt is. Ez sokszor a természet különös megnyilvánulásaiban, az emberi kapcsolatokban, a betegség és a halál jelenségeiben vált láthatóvá

\section{A vírus jelensége}

A jelen járványhelyzet során merült fel a kérdés: vajon a baktériumok és a vírusok is Isten teremtményei vagy ezek az ősbűn következményei? A baktériumok mikroszkopikus nagyságú, egysejtú élólények, az élet földi megjelenésének első formái, amelyek többségükben hasznosak. Az emberi test számára is szükségesek a szervezet jó múködéséhez. Ám vannak súlyosabb formái is, amelyek épp járványokban (kolera, gümőkór [tuberkulózis], agyhártyagyulladás, tífusz) okoznak gondot. Ezek a kórokozó baktériumok még az egészséges szervezetben is jelen lehetnek, de nem fejtik ki hatásukat, csak akkor, ha „megfelelő talajra" találnak. A kórokozó vírusok azonban súlyos betegségeket eredményeznek. Ha a feltett kérdésre válaszolni akarunk, azt mondhatjuk, hogy Isten teremtette a baktériumokat és a vírusokat, amikor a világot létrehozta. De ez nem jelenti azt, hogy egyúttal azok káros voltát is megalkotta. Ez - ahogy a kinyilatkoztatás is mondja - a bún és a bukás következménye, mely először az emberi személyt, majd a természet egészét is érintette, és így a kettő egymásra hatásában érvényesül. A betegség, a romlás és a halál a búnbeesés előtt nem létezett. Nem volt küzdelem az élő szervezetekben az „ellenfelek” között, sem a természetben, amint erról szimbolikusan ír Izajás próféta: „Együtt lakik a farkas a báránnyal és a párduc együtt tanyázik a gödölyével. Együtt legelészik a borjú és az oroszlán... Sehol nem ártanak s nem pusztítanak az én szent hegyemen, mert a Föld úgy tele lesz az Úr ismeretével, mint ahogy betöltik a vizek a tengert" (Iz 11,6-9). Az első ember szervezetét ebben az értelemben nem sújtották a baktériumok és vírusok kórokozó hatásai, mint jelenlegi helyzetünkben. Ezt a kezdeti állapotot nyerjük vissza az örök élettel, amirôl Jézus szintén képi módon beszél: „Akik hisznek, azokat ezek a jelek fogják kísérni. A nevemben [...] kígyókat vehetnek kezükbe és ha valami mérget isznak, nem árt nekik" (Mk 16,17-18). Tanításában Jézus megerősíti: „Hatal- mat adtam nektek, hogy kígyókon és skorpiókon járjatok, hogy minden ellenséges erőn úrrá legyetek. Nem fog ártani nektek semmi" (Lk 10,19).

\section{Az ember személyes büne}

Ezen a ponton kell megkérdeznünk, hogy vajon mi a bún szerepe a betegség, a halál és a romlás jelenségeiben. Láthattuk, hogy az emberi természet bukása ősszüleink bünének köszönhető. Az egyház szerint nem osztozunk személyes búnükben, csak annak hatásában. Ugyanakkor a leszármazottakban a megtapasztalt következmények még súlyosabbak is lehetnek. Itt láthatjuk a természet és a környezet tudatos pusztítását. (Ferenc pápa külön tanácskozást hívott össze Amazóniáról, amelyet a világ tüdejének is neveznek [2019. október 7-26.]. Ez az egyházi tanácskozás a pápa Laudato si' kezdetú körlevelével is kapcsolatba hozható. A „közös ház”, vagyis a környezetünk megvédésének fontos dokumentuma volt ez 2015-ben. A tanácskozás dokumentumát 2020. február 12-én mutatták be, a „Querida Amazonia” - Kedves Amazónia kezdetú apostoli buzdítást, mely a természet kincseinek a megőrzésére szólít fel.) A jelenlegi ökológiai válság is azt mutatja, hogy igenis kapcsolat van az emberi búnök és a természet jelenlegi állapota között. Mind egyénileg, mind közösségileg vállalni kell a felelősséget tetteinkért, tudva, hogy a felelősségláncolatok összetartoznak.

Azzal, hogy a kinyilatkoztatás a természet romlását Ádám bűnére vezeti vissza, ez még nem jelenti azt, hogy ő az egyedüli felelős a jelenlegi helyzetért. Pál apostol világítja ezt meg: „Amint egy ember által lépett a világba a bűn, majd a bûn folyományaként a halál, így a halál minden embernek osztályrésze lett, mert mindannyian vétkeztek" (Róm 5,12). Így minden ember, jóllehet nem eleve felelős az Ádámtól örökölt bajokért, személyes bứne mégis ehhez kapcsolódik, és ez voltaképpen minden embert összeköt.

Ezen a ponton azonban nem szabad megfeledkeznünk éppen a kinyilatkoztatás magyarázatában megjelenő Sátán szerepéről. „A világ fejedelme” megtéveszti a mindenkori embert (vö. Jn 12,31, 14,30 és 8,44), és megfosztja azoktól a tulajdonságoktól, amelyekkel Isten ajándékozta meg. A Sátán bizonyos múködési lehetőséget kap, de Isten meghagyja az ember szabadságát is. Így a bűnnek a következményét tapasztalja meg később minden ember, mely azután fejlődik, kiterjed, megerősödik és mintegy megtestesül a sötétség és a gonoszság hatalma következtében. (Ennek a jelenségnek a leírását láthatjuk az ószövetségi Jób könyvében, ahol az Úr mondja a Sátánnak: „Nos, a kezedbe adom, csak az életét kíméld” [Jób 2,6]. Ugyanennek a sötét hatalomnak a bennfoglalását fedezzük fel Péter apostol beszédében is: „Isten felkente a názáreti Jézust Szentlélekkel és hatalommal, s ahol csak járt, jót tett, meggyógyította az összes ördögtől megszállottat” [ApCsel 10,38].) 
Itt olyan titkokkal találkozunk, amelyeket nehéz azonnal értelmezni, de nagyon jól tudjuk, hogy Isten nem fenyegetni akarja az embereket, hanem tanítani.

\section{Az egyház támogatása a bajban}

A bajok nem feltétlenül köthetők az egyének bûneihez, hanem tulajdonképpen az egész emberiség bưneihez. Ezért szükséges, hogy mindenki valamiképpen felelősnek érezze magát a másikért, ha látja, hogy a bünök folytatódnak. Itt a hívő ember magatartása a búnbánattartás, amint ezt már oly sokszor megmutatta Ferenc pápa is, és épp a mostani járvány kezdetén, amikor 2020. március 27-én az üres római Szent Péter téren imádkozott.

Ezzel párhuzamosan a szentatya és a püspökök egyaránt a józan védekezésre szólítottak fel. Így együtt tudtak múködni az egyes közéleti hatóságok rendelkezéseivel, jóllehet éppen a vallásosság kinyilvánításában is korlátokat kellett érvényesíteni.

Az elmúlt évek tapasztalata azonban megmutatta, hogy a megpróbáltatások mindig próbatételt jelentenek. Akár a távolságtartást, akár a maszkviselést vagy a szokásos kapcsolati rendszer felfüggesztését tekintjük, ez egyaránt sújtotta a mindennapi életet és az egyházak életét is. Tudva, hogy a járványhelyzet félelmet, nyugtalanságot és szorongást idézett elő, a keresztény válasz ezekre nem lehetett más, mint az élet komolyan vétele. A modern világ, amelyben a hit és a kereszténység hanyatlóban van, megfosztja az embereket attól, hogy életük helyes célját és értelmét felismerjék, és ezzel összefüggésben a halálra is fel tudjanak készülni. A vírushelyzet azonban páratlan emberi magatartásformákat és értékeket is felmutatott, főképp az egészségügyben dolgozók részéről. Talán önkéntelenül is a másokért cselekvők között az ember jobbik énje nyilvánult meg, úgyhogy képesek voltak áldozatot is hozni. Róluk is mondta Jézus, éppen a szenvedése előtti estén, hogy „senkinek sincs nagyobb szeretete, mint annak, aki életét adja barátaiért” (Jn 15,13). Éppen a szeretet lehet a gyógyszer a vírus ellen, amely legyőzi a félelmet (vö. Jn 4,18).

\section{Az élő hit gyógyszere}

Krisztus halál fölötti győzelme pedig egy fizikai valóság, nemcsak spirituális. Krisztus valóságosan győzte le a ha- lált és támadt fel saját emberségében mindannyiunkért. Ez a tény nemcsak egy szubjektív hit felfogása, hanem éppen a mostani válsághelyzet idején egy meggyőződés fogható valósága. Erről írt Szent Pál a korinthusiaknak: „Ha Krisztus nem támad fel, semmit sem ér a hitetek” (1Kor 15,17). Krisztus győzelme nemcsak a fizikai adottságokon, a romláson és a halálon nyilvánult meg, hanem a bún és az ehhez kapcsolódó félelem fölött is. Ezzel együtt a Sátán és a gonoszság erőit is legyőzte.

A Zsidókhoz irt levél tanításában olvassuk: „senkit meg ne keményítsen a csalárd bün, mert Krisztus részesei vagyunk, de csak úgy, ha kezdeti szilárd hitünkben mindvégig állhatatosan kitartunk" (Zsid 3,14). Ezt a hitet nyújtja a keresztség, amely teljesen Krisztushoz kapcsol, aki „halálával legyőzte azt, aki a halálon uralkodott [...] és felszabadította azokat, akiket a haláltól való félelem egész életükre rabszolgává tett” (Zsid 2,14-15).

Ilyen tudással és ismeretekkel, személyes hittel és meggyőződéssel az emberiség üdvtörténetének és a világ eseményeinek helyes mérlegelésével, valamint Jézus Krisztus megváltó múvében való részesedéssel nemcsak a földi élet viszontagságai közepette tudunk helytállni személyes, családi és közösségi feladataink során, hanem Isten tervét az emberiséggel kapcsolatos elgondolásai szerint tudjuk érzékelni, rábízva magunkat, szeretteinket és végső soron az egész emberiséget a világ üdvözítőjére, aki ma is így szól hozzánk: „Ne legyen nyugtalan a szívetek! Higgyetek az Istenben és bennem is higgyetek!” (Jn 14,1)

\section{Irodalomjegyzék}

Eftychiadis, A. C. (1997) The Early Types of Hospitals During the First Three Christian Centuries and the Early Byzantine Period. Theologia, 68, 288-311.

Ferenc pápa (2015) Laudato si’ körlevél. Budapest, Szent István Társulat

Ferenc pápa (2020) Querida Amazonia apostoli buzdítás. https:// www.vatican.va/content/francesco/en/apost_exhortations/documents/papa-francesco_esortazione-ap_20200202_querida-amazonia.html

Heidegger, M. (1980) Sein und Zeit. (11. ed.) Tübingen, Max Niemeyer Verlag

Karthágói Szent Ciprián (1999) Ad Demetrianum (Válasz a pogány vádak ellen). Ókeresztény Írók 15. Budapest, Szent István Társulat, 300-323.

Tertullianus (1986) Apologeticum (Védőbeszéd). Ókeresztény Írók 12. Budapest, Szent István Társulat, 61-149.

A cikk a Creative Commons Attribution 4.0 International License (https://creativecommons.org/licenses/by/4.0/) feltételei szerint publikált Open Access közlemény, melynek szellemében a cikk bármilyen médiumban szabadon felhasználható, megosztható és újraközölhető, feltéve, hogy az eredeti szerző és a közlés helye, illetve a CC License linkje és az esetlegesen végrehajtott módosítások feltüntetésre kerülnek. (SID_1) 